\title{
Pre-Sowing Seed Invigouration of Direct Seeded Rice for Early Seedling Vigour and Improvement of Yield in Organic Condition
}

\author{
Prithviraj Pegu $^{1 *}$, Sharmila Dutta Deka ${ }^{1}$, Pranab Dutta $^{2}$ and Prakash Borah ${ }^{1}$ \\ ${ }^{1}$ Department of Plant Breeding \& Genetics, Assam Agricultural University, \\ Jorhat, Assam, India \\ ${ }^{2}$ Department of Plant Pathology, Assam Agricultural University, Jorhat, Assam, India \\ *Corresponding author
}

\begin{tabular}{|c|}
\hline Keywords \\
\hline $\begin{array}{l}\text { Direct seeding, bio } \\
\text { priming, seed } \\
\text { vigour, spikelet } \\
\text { fertility, seed yield }\end{array}$ \\
\hline Article Info \\
\hline $\begin{array}{l}\text { Accepted: } \\
\text { 18 August } 2019 \\
\text { Available Online: } \\
\text { 10 September } 2019\end{array}$ \\
\hline
\end{tabular}

\section{A B S T R A C T}

An investigation was carried out using 'Luit' variety of paddy (Oryza sativa L. indica) seeds to see the effects pre sowing seed treatment using different bioagents viz local commercial bio-formulations Org-Trichojal, Org-Metajal, OrgBeauverijal, three different commercial cold adaptive microbial consortiums and also priming with Zinc oxide nano-particle in order to improve field performance. In the present investigation, Beauverijal was found to be the best bio-agent for seed treatment as the results indicate better early seedling growth followed by higher number of seeds/panicle, seed yield and less disease infestation. Bio-agents viz. Trichojal and Metajal were also found to be effective in lowering the disease incidence and increase in seedling vigour followed by better yield performance. Comparative performance of Microbial consortium (C4), Microbial consortium (C7), although designated as cold adaptive strains, does not impart any significant influence in enhancing seed vigour and early seedling growth. Performance of nano-priming is found to better than hydration and cold tolerant microbial consortium for most of the characters. The better adaptability of local commercial bio-agents in Trichojal, Metajal, and Beauverijal may lead to better performance in seed vigour, early seedling growth and final seed production.

\section{Introduction}

Rice (Oryza sativa L.) is one of the most important and extensively grown food crops, feeding more than half of the global population (Virmani, 1999). It is the staple food for a larger segment of the Asian population. About $90 \%$ of rice is grown and consumed in Asian continent alone. Rice is cultivated all around the globe in an area of 167 million hectares, with a total production of 769.9 million tonnes and productivity of $4636.6 \mathrm{~kg} / \mathrm{ha}$ (FAOSTAT, 2018). India is the second-largest producer of rice after China, accounting for $20 \%$ of total rice production in the world. 
Organic seed and crop production in rice have various limitations besides its low productivity and challenges of field establishment under direct-seeded condition. However, the limitations are compensated with higher market price along with various health benefits. There is an emerging need for development of techniques for better crop establishment and crop protection in organic crop and seed production. Bio-priming is a modern technique of seed treatment that integrates biological (inoculation of seed with beneficial organism to protect seed) and physiological aspects (seed hydration) of disease control. Biological seed treatments may provide an alternative to chemical control (Reddy P.P. 2012). Besides a faster speed of emergence, there are several benefits of using primed seed. Priming enables a seed to germinate and emerge even under adverse agro-climatic conditions such as cold and wet or extreme heat. Uniform emergence helps optimize harvesting efficiency which can increase yield potential. There is increasing interest in the use of bio-agents as a means of growth promotion through the efficient use of plant growth promoting bio-formulations as an economic and efficient means of treating crops (Murunde \& Wainwright, 2018). Hence, biopriming may play a significant role in organic crop production. Besides bio-agents, few nano-priming agents might also play a crucial role in early seedling establishment and improvement of ultimate yield in organic condition. To develop sustainable nanoagriculture, $\mathrm{ZnO}$ nanoparticles have been prepared using brown seaweed Turbinaria ornate extract as a priming agent to promote rice seed quality and crop yield attributing to rice seeds (Itroutwar et al., 2019).

Direct seeding methods have played a critical role in the intensification of Asian rice systems. This method mostly helps in achieving higher water-use efficiency. Although, low rainfall at planting time, tends to low production risk. The traditional system of direct seeding in some rain-fed areas of eastern India has evolved partly in response to rainfall uncertainty (Fujisaka et al., 1993). In Assam Ahu rice covers 4 lakh hectares (16\% of gross rice area) to contribute $11 \%$ of rice production. These are photoperiod insensitive and can be grown as both early $a h u$; a preflood crop in flood affected areas as well as normal $a h u$, grown in the areas where risk of flood is minimal. The problems related to early ahu rice cultivation is low temperature at seedling stage can cause stunted seedling growth, yellowing of leaves, leaf spots, slow and delayed tillering and non-synchronous and delayed flowering (Lal et al., 2013). Seedling mortality takes place during nursery stage due to long cold spells. The present study is an attempt to strengthen the early seedling growth by using different bio-formulations to overcome cold stress during early ahu season in organic condition.

\section{Materials and Methods}

The present study was carried out at Assam Agricultural University, Jorhat which is situated in the Upper Brahmaputra Valley Zone of Assam lying at $26^{\circ} 45^{\prime} \mathrm{N}$ latitude and $94^{\circ} 12^{\prime} \mathrm{E}$ longitude at an elevation of $86.6 \mathrm{~m}$ above the mean sea level. Certified seeds of a popular recommended rice variety Luit were taken for the study. Details of seed treatments are given in table 1. Three different local commercial bio-formulations and three cold adaptive bio-strains were employed in the present study. Besides this, seed treatment with Zinc Oxide nano-particles were also done along with hydration treatments. Experiment was laid out following randomized block design with three replications in the organic block using direct-seeding method by applying farmyard manure(FYM) @ 5 ton/ha. Recommended intercultural operation of weeding and irrigation were done periodically. Observations were taken for different seedling 
vigour, field emergence, and fertility characters and yield and its attributes were taken in respective phases. Germination \% was recorded following method
ISTA2004.Seed vigour index was calculated by following method given by Copeland and McDonald, 1985.

Table.1 Treatments for field evaluation

\begin{tabular}{|c|c|c|}
\hline Treatment No. & Treatment dose & Source \\
\hline $\mathbf{T}_{1}$ & Control (Untreated) without hydration & - \\
\hline $\mathbf{T}_{2}$ & $\begin{array}{l}\text { Seed hydration/hydro priming- soaking in } \\
\text { water for } 6 \text { hours }\end{array}$ & - \\
\hline $\mathbf{T}_{\mathbf{3}}$ & $\begin{array}{l}\text { Seed Priming with Org-Metajal (contains } \\
\text { Metarhizium anisopliae) @ } \\
5 \mathrm{ml} / \text { liter water/kg of seeds for } 6 \text { hours }\end{array}$ & $\begin{array}{l}\text { Department of Plant Pathology, } \\
\text { AAU, Jorhat }\end{array}$ \\
\hline $\mathbf{T}_{4}$ & $\begin{array}{l}\text { Seed Priming with Org- Trichojal (contains } \\
\text { Trichoderma harzianum) @ } \\
5 \mathrm{ml} / \text { liter water } / \mathrm{kg} \text { of seeds for } 6 \text { hours }\end{array}$ & $\begin{array}{l}\text { Department of Plant Pathology, } \\
\text { AAU, Jorhat }\end{array}$ \\
\hline $\mathbf{T}_{5}$ & $\begin{array}{l}\text { Seed Priming with Org-Beauverijal } \\
\text { (contains Beauveria bassiana @ } \\
5 \mathrm{ml} / \text { /liter water } / \mathrm{kg} \text { of seeds for } 6 \text { hours }\end{array}$ & $\begin{array}{l}\text { Department of Plant Pathology, } \\
\text { AAU, Jorhat }\end{array}$ \\
\hline $\mathbf{T}_{6}$ & $\begin{array}{l}\text { Seed priming with cold adaptive Plant } \\
\text { growth promoting bacteria formulation } \\
\text { (PGPB)@ } 5 \mathrm{ml} / \text { liter water } / \mathrm{kg} \text { seeds for } 6 \\
\text { hours }\end{array}$ & NBAIM, Mau \\
\hline $\mathbf{T}_{7}$ & $\begin{array}{l}\text { Seeds are soaked for } 6 \text { hours than treated } \\
\text { with Charcoal based cold-tolerant PGPB } \\
\text { consortium (C4) @ } 5 \mathrm{mg} / \mathrm{kg} \text { seed }\end{array}$ & ICAR - VPKAS, Almora \\
\hline $\mathbf{T}_{8}$ & $\begin{array}{l}\text { Seeds are soaked for } 6 \text { hours than treated } \\
\text { with Charcoal based cold-tolerant PGPB } \\
\text { consortium (C4) @ } 5 \mathrm{mg} / \mathrm{kg} \text { seed }\end{array}$ & ICAR - VPKAS, Almora \\
\hline
\end{tabular}

\section{Results and Discussions}

Among all the field observations, field emergence was highest in seed treated with $\mathrm{T}_{3}$, Org-Metajal(85.02\%). Seedling height was highest in $\mathrm{T}_{5}$, Org-Beauverijal $(45.49 \mathrm{~cm})$ and also Seed Vigour Index (SVI)-I was highest in seed treated with Org-Beauverijal (table 2). Nano-primed seeds showed better field emergence in comparison to cold adaptive PGPB and microbial consortium (table 2). Plant height was recorded as highest in seed treated with Org-Trichojal $(60.18 \mathrm{~cm})\left(\mathrm{T}_{4}\right)$ followed by $\mathrm{T}_{3}$, Org-Metajal $(59.71 \mathrm{~cm})$. Chlorophyll a \& b content was recorded highest in seed treated with Trichojal and $\mathrm{ZnO}$ Nano-particles respectively (table 3 ). Whereas leaf area was recorded highest in $\mathrm{T}_{3}, \mathrm{Org}$ Metajal followed by hydro priming $\left(\mathrm{T}_{2}\right)$. While recording fertility characters, highest Pollen fertility was observed in $\mathrm{T}_{3}$,Org-Metajal (97.49\%) followed by $\mathrm{T}_{4}$,Org-Trichojal (93.61\%) and $\mathrm{T}_{5}$,Org-Beauverijal $(90.72 \%)$ (table 3). Lowest pollen fertility was observed in $\mathrm{T}_{1}$ (control, $76.61 \%$ ). Whereas highest spikelet fertility was observed in $\mathrm{T}_{9}(\mathrm{ZnO}$ Nano priming $(82.17 \%)$ followed by $\mathrm{Org}_{-}$ Beauverijal $(81.62 \%)$ and $\mathrm{T}_{6}$ (cold adaptive PGPB) $(80.22 \%)$. For yield attributes, seeds /panicle was highest in $\mathrm{T}_{5}$, Org-Beuverijal 
(149.23) followed by Org- Trichojal $\mathrm{T}_{4}$ (140.77), whereas yield/plant was found to be highest in $\mathrm{T}_{4}$ Org-Trichojal (14.31gm) followed by Org-Beuverijal (13.21gm). However significant increase in seed yield/plant was observed in all the treatments over control (table 4). Lowest disease incidence was found in seed treated with $\mathrm{Org}$ Beuverijal (29.08). However, Disease incidence was lower in all the treatments in comparison to control.(table 3 )

\section{Response of bio-agents on early seedling growth}

The response of bio priming treatments was found significantly variable. However, highest field emergence was observed in $\mathrm{T}_{3}$ (OrgMetajal) followed by $\mathrm{T}_{5}$ (Org-Beauverijal) seeds. Higher seedling height in all the priming treatments as compared to the control implies significant response of treatments on seedling growth. Due to uniform cell division proceeds in all the cells ensuring uniform development of all parts of the seedling; this may be the basic reason of higher seedling height and plant height in all the priming treatments as compared to the control. Reports are available on seed enhancement with bioagents improves the germination, vigour and uniformity of seedling emergence during early seedling growth. (Krishna et al., 2008; Fallahi et al., 2011). In the present study, seedling height differed significantly in response to various priming treatments. Highest seedling height was observed in $\mathrm{T}_{5}$ (Org-Beauverijal, $45.49 \mathrm{~cm}$.) followed by viz. and $\mathrm{T}_{4}$. (OrgTrichojal, $42.47 \mathrm{~cm}$ ).

The microbial cultures reported to have impact on regulations of growth hormones (Doni et al., 2014; Zheng and Shetty, 2000; Hameed and Iqbal, 2010). The better adaptability of 1 bio-agents in Trichojal, Metajal and Beauverijal may lead to better performance in seed vigour and other seed production qualities as these formulations were constituted with local microbial agents.

Effects of seed treatment on seedling vigour

The assessment of seed vigour has many important implications to evaluate seed physiological potential. Seed vigour and its associations with field stand establishment and crop productivity is an important area of seed quality assessment. In the present study, the highest seed vigour index-I was observed in $\mathrm{T}_{5}$ (Org-Beauverijal, 3803.84).Chlorophyll a, and Chlorophyll $\mathrm{b}$ content showed variability in response to different priming treatments, highest in $\mathrm{T}_{4}$ (Org-Trichojal, 13.67) and in $\mathrm{T}_{8}$ (Charcoal based cold-tolerant PGPB consortium C7, 5.05). Various reports are available in this direction. Panhwar et al., (2017) also reported that biochemical parameter like chlorophyll content showed a significant increase due to seed priming.

\section{Effect of seed treatments on vegetative growth of rice}

The vegetative stage of the crop is an important phase where maximum dry matter accumulation takes place. The vegetative development of the crops depends on various factors including climate, soil, nutritional status and also the seed quality. We have recorded the three most important growth parameters viz. plant height, the number of effective tillers and leaf area to evaluate the response of different bio-agents on these parameters. The plant height was found to be responsive due to treatment effect. The number of tillers per plant also varied significantly. Our study is in accordance to Rehman et al., 2011 and Yadav et al., 2018 who reported the use of microbes in combination with reduced fertilizer dose is beneficial to increase the growth and productivity of the baby corn for sustainable agriculture. 
Effect of seed treatments on the fertility characters

Highest Pollen fertility was observed in $\mathrm{T}_{3}$ (Org-Metajal, 97.49) followed by $\mathrm{T}_{4}\left(\mathrm{Org}_{-}\right.$ Trichojal, 93.61) and $\mathrm{T}_{5}$ (Org-Beauverijal, 90.72).Lowest pollen fertility was observed in $\mathrm{T}_{1}$ (control, 76.61). Highest spikelet fertility was observed in $\mathrm{T}_{9}$ ( $\mathrm{ZnO}$ Nano priming, 82.17) followed by $\mathrm{T}_{5}$ (Org-Beauverijal, 81.62) and $\mathrm{T}_{6}$ (cold adaptive PGPB, 80.22).There are reports on pollen viability and spikelet fertility which are more sensitive under stress condition (Saragih et.al. 2013).In the present study, pollen and spikelet fertility is found to be higher in treated seeds as compared to control and hydration treatment.

This may be attributed due to better root growth and vegetative growth in treated plants which enables plants to absorb water and plant nutrients more efficiently and translated into better fertility.

Effect on seed priming on yield and disease incidence

There is a significant difference due to

Table.2 Effect of seed enhancement treatments on seedling growth

\begin{tabular}{|c|c|c|c|c|c|}
\hline Treatment & $\begin{array}{c}\text { Field } \\
\text { Emergence } \\
(\mathbf{\%})\end{array}$ & $\begin{array}{c}\text { Seed } \\
\text { Vigour } \\
\text { Index-I }\end{array}$ & $\begin{array}{c}\text { Seedling } \\
\text { Height(cm) }\end{array}$ & $\begin{array}{c}\text { Plant } \\
\text { Height(cm) }\end{array}$ & $\begin{array}{c}\text { No. } \\
\text { of } \\
\text { tillers }\end{array}$ \\
\hline $\mathbf{T}_{\mathbf{1}}$ & 73.08 & 2721.40 & 37.23 & 53.59 & 6.57 \\
\hline $\mathbf{T}_{\mathbf{2}}$ & 78.92 & 3246.34 & 41.13 & 57.49 & 6.57 \\
\hline $\mathbf{T}_{\mathbf{3}}$ & 85.02 & 3552.52 & 41.79 & 59.45 & 7.67 \\
\hline $\mathbf{T}_{\mathbf{4}}$ & 80.39 & 3414.76 & 42.47 & 60.18 & 7.89 \\
\hline $\mathbf{T}_{\mathbf{5}}$ & 83.61 & 3803.84 & 45.49 & 59.71 & 8.72 \\
\hline $\mathbf{T}_{\mathbf{6}}$ & 81.12 & 3189.24 & 39.32 & 56.86 & 7.04 \\
\hline $\mathbf{T}_{\mathbf{7}}$ & 78.09 & 3212.33 & 41.15 & 56.72 & 6.58 \\
\hline $\mathbf{T}_{\mathbf{8}}$ & 77.93 & 3203.81 & 41.12 & 56.72 & 6.81 \\
\hline $\mathbf{T}_{\mathbf{9}}$ & 82.54 & 3479.16 & 42.15 & 59.20 & 7.23 \\
\hline $\mathbf{C D} \mathbf{5 \%})$ & $2.54^{*}$ & $221.27^{*}$ & $2.62^{*}$ & $2.24^{*}$ & $1.3 *$ \\
\hline $\mathbf{C D}(\mathbf{1 \%})$ & $3.50^{* *}$ & $304.87^{* *}$ & $3.6^{* *}$ & $3.09^{* *}$ & 1.9 \\
\hline
\end{tabular}

* Significant at $5 \%,{ }^{* *}$ Significant at $1 \%$ probability level (indicates the same for table $3 \& 4$ ) biotic stress. $\mathrm{T}_{4}$ (Org-Trichojal, 31.51) (Table 2). statistically significant. (Org-Trichojal, 14.31) followed by $\mathrm{T}_{5}\left(\mathrm{Org}_{-}\right.$ Beauverijal). Sukanya et al., (2018) reported that bio-priming affects plants by different indirect means viz., phyto-hormones production stimulation, modulation in different secondary metabolites, alteration in gene expression, tolerance to abiotic and

treatments on disease incidence as indicated by analysis of variance. Lowest disease incidence was observed in the $\mathrm{T}_{5}$ ( $\mathrm{Org}$ Beauverijal, 29.08\%) followed by treatment

Reports are available that resistance against diseases by up-regulation of plant defence hormones salicylic acid, ethylene, and jasmonic acid signalling in plants treated with various bio-priming agents (Van Wees et al.,

The response of priming treatments for all the yield and yield attributing characters was

Highest yield per plant was obtained in $\mathrm{T}_{4}$ 
Table.3 Effect of seed enhancement treatments on seedling vigour, chlorophyll content (Chl), fertility parameters, leaf area \& disease incidence during field evaluation

\begin{tabular}{|c|c|c|c|c|c|c|}
\hline Treatment & Chl a & $\begin{array}{c}\text { Chl } \\
\mathbf{b}\end{array}$ & $\begin{array}{c}\text { Pollen } \\
\text { fertility } \\
\mathbf{( \% )}\end{array}$ & $\begin{array}{c}\text { Spikelet } \\
\text { fertility } \\
(\mathbf{\%})\end{array}$ & $\begin{array}{c}\text { Disease } \\
\text { Incidence } \\
(\boldsymbol{\%})\end{array}$ & $\begin{array}{c}\text { Leaf } \\
\text { Area(cm }\end{array}$ \\
\hline $\mathbf{T}_{\mathbf{1}}$ & 8.94 & 3.67 & 76.61 & 72.64 & 57.92 & 28.96 \\
\hline $\mathbf{T}_{\mathbf{2}}$ & 8.88 & 4.16 & 86.25 & 77.50 & 52.55 & 26.28 \\
\hline $\mathbf{T}_{\mathbf{3}}$ & 9.93 & 3.67 & 97.50 & 79.52 & 33.00 & 16.50 \\
\hline $\mathbf{T}_{\mathbf{4}}$ & 13.67 & 4.61 & 93.61 & 78.82 & 31.52 & 15.76 \\
\hline $\mathbf{T}_{\mathbf{5}}$ & 9.62 & 2.50 & 90.72 & 81.62 & 29.08 & 14.54 \\
\hline $\mathbf{T}_{\mathbf{6}}$ & 9.29 & 2.02 & 87.64 & 80.22 & 34.23 & 17.12 \\
\hline $\mathbf{T}_{\mathbf{7}}$ & 10.12 & 3.46 & 80.65 & 78.42 & 47.14 & 23.57 \\
\hline $\mathbf{T}_{\mathbf{8}}$ & 12.48 & 5.05 & 87.46 & 77.96 & 42.29 & 21.14 \\
\hline $\mathbf{T}_{\mathbf{9}}$ & 9.73 & 3.89 & 90.13 & 82.18 & 31.87 & 15.94 \\
\hline $\mathbf{C D} \mathbf{( 5 \% )}$ & $1.94 *$ & $1.83 *$ & $1.98 *$ & $1.44 *$ & $4.61 *$ & $5.04 *$ \\
\hline $\mathbf{C D}(\mathbf{1 \%})$ & $2.82 * *$ & 2.67 & $2.73 * *$ & $1.98 * *$ & $6.35 * *$ & 7.33 \\
\hline & & & & & & \\
\hline
\end{tabular}

Table.4 Effect of seed enhancement treatments on seed yield/plant and yield related attributes in field evaluation

\begin{tabular}{|c|c|c|c|c|}
\hline Treatment & $\begin{array}{c}\text { Panicle } \\
\text { Length(cm) }\end{array}$ & $\begin{array}{c}\text { No. of } \\
\text { seeds/panicle }\end{array}$ & $\begin{array}{c}\text { 1000 seed } \\
\text { weight(gm.) }\end{array}$ & $\begin{array}{c}\text { Seed } \\
\text { yield/plant(gm.) }\end{array}$ \\
\hline $\mathbf{T}_{\mathbf{1}}$ & 24.01 & 80.67 & 17.47 & 10.09 \\
\hline $\mathbf{T}_{\mathbf{2}}$ & 24.68 & 117.66 & 17.58 & 10.64 \\
\hline $\mathbf{T}_{\mathbf{3}}$ & 24.39 & 130.25 & 18.08 & 12.53 \\
\hline $\mathbf{T}_{\mathbf{4}}$ & 24.30 & 140.77 & 18.07 & 14.31 \\
\hline $\mathbf{T}_{\mathbf{5}}$ & 23.87 & 149.23 & 17.76 & 13.12 \\
\hline $\mathbf{T}_{\mathbf{6}}$ & 23.99 & 95.16 & 17.50 & 11.82 \\
\hline $\mathbf{T}_{\mathbf{7}}$ & 23.72 & 81.01 & 18.58 & 11.86 \\
\hline $\mathbf{T}_{\mathbf{8}}$ & 23.36 & 85.13 & 18.38 & 11.36 \\
\hline $\mathbf{T}_{\mathbf{9}}$ & 24.68 & 95.83 & 17.84 & 12.49 \\
\hline $\mathbf{C D}(\mathbf{5 \%})$ & $1.06 *$ & $11.59 *$ & $1.05 *$ & $1.52 *$ \\
\hline $\mathbf{C D}(\mathbf{1 \%})$ & 1.46 & $15.97 * *$ & 1.45 & $2.1 * *$ \\
\hline
\end{tabular}

Significant variation for seed yield/plant for different bio priming treatments indicates that, there is a possibility of improving yield with the present set of priming agents with proper nutrient management practices.

This warrants planning of experiment with various enriched bio-agents which might result in yield advantage with priming technology. Genetic potential for the yield of a particular variety is affected by external environmental factors. There are reports on the promotion of lateral root growth and root hair development of Arabidopsis seedlings via the production of auxin, indole-3-acetic acid (IAA) using Trichoderma as bio-priming agent(Contreras-Cornejo et al., 2009). 
The present investigation signifies better adaptability of local bio-agents in OrgTrichojal, Org-Metajal and Org-Beauverijal which may lead to better performance in seed vigour and other seed production qualities. The significant role of local micro flora in improvement of seed vigour characteristics indicates its importance in exploration and characterization for use in amendments of soil and seed characters during seed production process.

\section{Acknowledgement}

The authors acknowledge with thanks for the supply of cold adaptive bio-formulations from NBAIM, Mau, and ICAR - VPKAS, Almora.

\section{References}

Contreras-Cornejo, H. A., Macías-Rodríguez, L., Cortés-Penagos, C., \& López-Bucio, J. (2009). Trichoderma virens, a plant beneficial fungus, enhances biomass production and promotes lateral root growth through an auxin-dependent mechanism in Arabidopsis. Plant physiology, 149(3), 1579-1592.

Doni, F., Isahak, A., Zain, C. R. C. M., \& Yusoff, W. M. W. (2014). Physiological and growth response of rice plants (Oryza sativa L.) to Trichoderma spp. inoculants. Amb Express, 4(1), 45.

Fallahi, J., Rezvani Moghaddam, P., Ghorbani, R., Amiri, M. B., \& Fallahpour, F. (2011). Effects of seed priming by biofertilizers on the growth characteristics of three wheat cultivars at the emergence period under greenhouse condition. In 10th International Conference of the International Society for Seed Science. Brazilian Association of Seeds Technology, Salvador, Brazil. p.286

FAOSTAT. (2018). Agricultural production database. Food and Agricultural
Organization of the United Nations, FAO, Rome, Italy. http://faostat.fao.org

Fujisaka, S., Moody, K., \& Ingram, K. (1993). A descriptive study of farming practices for dry seeded rainfed lowland rice in India, Indonesia, and Myanmar. Agriculture, ecosystems \& environment, 45(1-2), 115-128

Hameed, A., I. Afzal and N. Iqbal. 2010. Seed priming and salinity induced variations in wheat (Triticum aestivum L.) leaf protein profile. Seed Sci. Technol., 38: 236-241.

Itroutwar, P. D., Govindaraju, K., Tamilselvan, S., Kannan, M., Raja, K., \& Subramanian, K. S. (2019). SeaweedBased Biogenic ZnO Nanoparticles for Improving Agro-morphological Characteristics of Rice (Oryza sativa L.). Journal of Plant Growth Regulation, 1-12.

Krishna A, Patil C R, Raghavendra S M, Jakati M D. 2008. Effect of biofertilizers on seed germination and seedling quality of medicinal plants. Karnataka Journal of Agricultural Sciences. 21:588-590

Lal, B., Gautam, P., Panda, B. B., \& Raja, R. (2013). Boro Rice: A Way to Crop Intensification in Eastern India.

McCue, P., Zheng, Z., Pinkham, J. L., \& Shetty, K. (2000). A model for enhanced pea seedling vigour following low $\mathrm{pH}$ and salicylic acid treatments. Process Biochemistry, 35(6), 603-613.

Murunde, R., \& Wainwright, H. (2018). Biopriming to improve the seed germination, emergence and seedling growth of kale, carrot and onions, Global Journal of Agricultural Research, 6(3), 26-34.

Panhwar A., Muhammad \& Laghari, G. \& Chandio, M. \& Magsi, F. \& Mangi, S. \& Azeem M., Muhammad C., Naveed J., Shafi S., Hassan \& Rasheed, Abdul. (2017). Effect of seed priming durations 
on growth and yield of wheat varieties. 11. 8-16.

Reddy, P. P. (2012). Bio-priming of seeds. In Recent advances in crop protection (pp. 83-90). Springer, New Delhi.

Rehman, H.; Basra, S.M.A.; Farooq, M;Ahmed, N. and Afzal, I.(2011). Seed Priming with $\mathrm{CaCl}_{2}$ improves the stand establishment, yield and quality attributes in direct seeded rice (Oryza Sativa), International Journal of Agriculture and Biology, 13(5):786-790

Saragih, E. H., Hutagaol, P., Pasaribu, B., \& Djohar, S. (2013). Individual attributes of change readiness in Indonesian television companies experiencing corporate transformational change-a quantitative approach using structural equation modeling. International Journal of Innovations in Business, 2(1), 60

Sukanya, V., Patel, R.M., Suthar, K.P. and
Singh, D., (2018). An Overview: Mechanism Involved in Bio-Priming Mediated Plant Growth Promotion, International Journal of Pure Applied Bioscience. 6(5): 771-783

Van Wees, S. C. M., van der Ent, S. \& Pieterse, C. M. J. (2008). Plant immune responses triggered by beneficial microbes. Curr Opin Plant Biol 11, 443448.

Virmani, S. S. (1999). Exploitation of heterosis for shifting the yield frontier in rice. The Genetics and Exploitation of Heterosis in Crops, (thegeneticsande), 423-438.

Yadav, R. S., Singh, V., Pal, S., Meena, S. K., Meena, V. S., Sarma, B. K. \& Rakshit, A. (2018). Seed bio-priming of baby corn emerged as a viable strategy for reducing mineral fertilizer use and increasing productivity. Scientia horticulturae, 241, 93-99.

\section{How to cite this article:}

Prithviraj Pegu, Sharmila Dutta Deka, Pranab Dutta and Prakash Borah 2019. Pre-Sowing Seed Invigouration of Direct Seeded Rice for Early Seedling Vigour and Improvement of Yield in Organic Condition. Int.J.Curr.Microbiol.App.Sci. 8(09): 1152-1159. doi: https://doi.org/10.20546/ijcmas.2019.809.132 